\title{
Systematic review of the use of phytobiotics in broiler nutrition
}

\author{
Revisão sistemática do uso de fitobióticos na nutrição de frangos de corte \\ Renata Gomes da Silveira Deminicis ${ }^{1 *}$, Camila Meneghetti ${ }^{1}$, Elizângela Bonfim de Oliveira ${ }^{1}$, Antônio \\ Amândio Pinto Garcia Júnior ${ }^{2}$, Ronaldo Vasconcelos Farias Filho ${ }^{2}$, Bruno Borges Deminicis ${ }^{3}$ \\ 1Universidade Estadual de Santa Cruz, Ilhéus, BA, Brasil. * Author for correspondence: renatademinicis@gmail.com \\ ${ }^{2}$ Universidade Estadual do Sudoeste da Bahia, Itapetinga, BA, Brasil. \\ ${ }^{3}$ Universidade Federal do Mato Grosso, Sinop, MT, Brasil.
}

Submission: 05/10/2020 / Acceptance: 14/12/2020

\begin{abstract}
The objective of this study was to conduct a systematic review of the literature on the use of phytogenics in broiler nutrition. A bibliographic survey was conducted for the years between 2009 and 2019, using the keywords "eubiotics," "phytobiotics," "essential oils," "phytogenic extracts," and corresponding words associated with the terms "broiler" and "poultry." The selected articles were grouped into the categories: animal performance, histomorphology of the intestinal wall, biochemical profile, carcass characteristics, and the effect on bacteria found in the intestine. After comparisons of several parameters on the use or non-use of phytogenics, it was found that replacing antibiotics with phytogenics contributes positively to performance, the histomorphology of the intestinal wall, the biochemical profile, carcass characteristics, and the number of bacteria found in the gut. In conclusion, based on several studies found in the literature, replacing antibiotics with phytogenic additives in broiler nutrition may be viable due to their lower residual impact on the final product, in addition to their positive effect on the parameters of animal production.
\end{abstract}

KEYWORDS: essential oils, phytogenic extracts, phytogenic additives, plant extracts, broiler.

\section{RESUMO}

Objetivou-se realizar uma revisão sistemática da literatura sobre o uso de fitogênicos na nutrição de frangos de corte. Foi realizado levantamento bibliográfico do período de 2009 a 2019. Foram utilizadas as palavras-chave utilizadas foram "eubióticos", "fitobióticos", "óleos essenciais" e "extratos fitogênicos" e suas correspondentes em inglês, "eubiotics" e "phytobiotics", "essential oils" e "phytogenic extracts" associada a palavra "frango de corte", e "poultry" em inglês. Os artigos selecionados foram agrupados nas categorias: desempenho zootécnico, histomorfologia da parede intestinal, perfil bioquímico do sangue, característica de carcaça e o efeito nas bactérias encontradas no intestino. Após comparações de diversos parâmetros sobre o uso ou não uso de fitogênicos, percebeu- se que a substituição dos antibióticos pelos fitogênicos pode ser considerado positiva para o desempenho, histomorfologia da parede intestinal, perfil bioquímico do sangue, característica de carcaça e número de bactérias encontradas no intestino. Sendo assim, foi concluído com base nos diversos trabalhos encontrados na literatura que a substituição dos antibióticos pelos aditivos fitogênicos na nutrição de frangos de corte pode ser viável, devido ao seu menor impacto residual no produto final, além de influenciar positivamente nos parâmetros de produção animal.

PALAVRAS-CHAVE: óleos essenciais, extratos fitogênicos, aditivos fitogênicos, extratos de plantas, frango de corte.

\section{INTRODUCTION}

In recent years, antibiotic additives as performance enhancers have been incorporated into broiler diets. However, following the ban on the use of antibiotics as performance enhancers in the European Union in 2006 and recently in North America, non-antibiotic substances with the potential to promote growth have instigated research for effective alternatives such as probiotics, organic substances, enzymes, and phytogenic feed additives, which have received more attention (PARASKEUAS et al. 2017).

Phytogenic feed additives are plant-based feed additives, natural substances used in animal nutrition, and they derive from herbs, spices, other plants and their extracts, and essential oils. Phytogenic feed additives have constant effects on poultry performance, mainly due to differences in origin, processing, and 
botanical composition. Herbs, spices, essential oils, and plant extracts contain a wide variety of chemical substances (HAFEEZ et al. 2016).

There is considerable interest in phytogenic feed additives for animal feed because of their ability to improve performance while maintaining a healthy intestinal environment. Phytogenics used as natural growth promoters in animal nutrition proved to provide a return on investment. They also proved to reduce ammonia, methane, and other greenhouse gas emissions (MURUGESAN et al. 2015).

The compounds originating from the special metabolism of vegetables have also demonstrated functions with antiviral, antioxidant, immunomodulatory, anti-inflammatory, and antifungal properties (MADHUPRIYA et al. 2018). With the ban on antibiotic use in animal nutrition, due to the emergent resistance to bacteria, alternative performance enhancers have come to the fore. In this regard, the objective of this study was to conduct a systematic review of the literature on the use of phytogenic feed additives in broiler nutrition.

\section{MATERIAL AND METHODS}

Based on conditions of the study, the Systematic Search Flow (SFF) method was employed to systematize the search process for articles in the literature. Both scientific and review articles were accessed through four search platforms (FERENHOF \& FERNANDES 2016): Google Academic $\AA$, Periodicals Capes $\AA$, Scielo $\AA$, and Scopus $\AA$. Complete articles on indexed journals were included and incomplete ones were excluded, which was how the articles were selected, organized, and standardized. Through software that organizes bibliographies and bibliographical references, it was possible to separate the answers for each of the searches.

The search criteria corresponded to the years between 2009 and 2019, using the keywords "eubiotics," "phytobiotics," "essential oils," "phytogenic extracts," and words associated with the terms "broiler" and "poultry". Articles published before 2009 and those referring to other subjects not relevant to the study were excluded.

From all the databases, 110 articles were found. Upon reading the articles' titles, some were repeated in different databases, while others did not fulfill the study criteria, resulting in 96 articles. The abstracts were read, and those that did not fall within the objective of this study were excluded. After reading the abstracts, 48 articles were selected, as they seemed to fulfill the initial criteria, and were read in full. In the final selection, literature review articles were excluded. Within this context, the articles were read and carefully selected, and their data were grouped into the following categories: animal performance, histomorphology of the intestinal wall, biochemical profile, carcass characteristics, the effect on bacteria found in the intestine. Therefore, different results and phytogenic feed additives used to substitute antibiotics as performance enhancers in broiler nutrition could be verified.

\section{RESULTS AND DISCUSSION}

Different species (Table 1) were examined in the use of phytogenic feed additives in broiler diets, mostly: Origanum vulgare (30.3\%), Thymus vulgaris (24.24\%), Allium sativum (15.15\%), Pimpinella anisum (15.15\%), Mentha arvensis (12.12\%), Cinnamomum sp. (9.09\%), and Citrus limonum $(9.09 \%)$. The majority pertained to an aromatic species and were rich in essential oils. In $54.8 \%$ of the studies on the effect of phytogenic feed additives, no antibiotic was used as a comparative parameter. As for the antibiotics applied in the studies, $9.09 \%$ used Oxytetracycline, 12.12\% applied Bacitracin methylene disalicylate, 9.09\% administered Avilamycin, and $15.15 \%$ used other antibiotics (Doxycycline, Monensin sodium, Salinomycin, Tylosin, and Toltrazuril). Bacitracin was the most commonly applied antibiotic in the studies, but there are concerns about the residual capacity left in the animal.

Volatile oils, also known as essential oils, are made up of a complex mixture of volatile, lipophilic, odorous, and liquid substances whose main active compounds are terpenoids and phenylpropanoids, wherein two or three components can be responsible for up to $85 \%$ of the total elements present in the compound, which directly contribute to its primary properties (ZHAl et al. 2018). According to the International Standard Organization (ISO), these compounds are obtained from part of a plant or the complete plant by means of hydrodistillation, steam distillation, or by pressing the pericarps of citrus fruits. The composition of a species' essential oil is genetically determined and specific to an organ, but environmental conditions can significantly alter its chemical characteristics (SIMÕES et al. 2017).

The essentials oils of Origanum vulgare and Thymus vulgaris have a high content of phenolic compounds, and the carvacrol and thymol monoterpenes are mainly responsible for their antibacterial and antioxidant activities, aside from having antimicrobial activity (BORGES et al. 2012). The main compounds 
act on the bacterial cell membrane and prevent mitosis, which causes dehydration in the cells and inhibits the survival of pathogenic bacteria.

Table 1. Plant species used as an alternative to performance-enhancing antibiotics in broiler nutrition.

\begin{tabular}{|c|c|c|c|c|}
\hline Author & Phytogenic species & Antibiotics* & $\begin{array}{l}\text { Poultry } \\
\text { lineage }\end{array}$ & $\begin{array}{l}\text { Evaluation } \\
\text { period }\end{array}$ \\
\hline PUVACA et al. (2015) & $\begin{array}{c}\text { Allium sativum; Piper nigrum; Capsicum } \\
\text { annuum. }\end{array}$ & - & Hubbard & $1-42$ days \\
\hline $\begin{array}{c}\text { HASHEMI \& } \\
\text { DAVOODI (2011) }\end{array}$ & Euphorbia hirta, & - & Cobb & $1-42$ days \\
\hline $\mathrm{CHO}$ et al. (2014) & Thymus vulgaris, Pimpinella anisum & Avilamycin ${ }^{1}$ & Ross & 1-35 days \\
\hline SINGH et al. (2015) & Cinnamomum cassia, Allium sativum & Oxytetracycline & IBL $80^{\Psi}$ & 1-35 days \\
\hline OLUKOSI et al. (2014) & Curcuma longa, Allium sativum & - & Ross & $1-21$ days \\
\hline PULICl et al. (2014) & $\begin{array}{c}\text { Origanum vulgare } \\
\text { Ocimum basilicum, Carum carvi, Laurus }\end{array}$ & Bacitracin $^{1}$ & Cobb & $1-42$ days \\
\hline KHATTAK et al. (2014) & $\begin{array}{c}\text { nobilis, Citrus limonum Risso, Origanum } \\
\text { vulgare, Salvia officinalis, Thymus } \\
\text { vulgaris }\end{array}$ & - & Ross & 1-42 days \\
\hline $\begin{array}{l}\text { BOZKURT et al. } \\
(2014)\end{array}$ & $\begin{array}{c}\text { Origanum vulgare, Cinnamomum } \\
\text { camphora, Thymus vulgaris, Citrus } \\
\text { limonum Risso }\end{array}$ & Salinomycin ${ }^{1}$ & Ross & $1-42$ days \\
\hline Ll et al. (2015) & Phytoncides Phytoncide & Tilosin ${ }^{2}$ & Ross & 1-35 days \\
\hline PATI et al. (2015) & Zingiber officinale & - & - & $1-49$ days \\
\hline WATI et al. (2015) & $\begin{array}{c}\text { Foeniculum vulgare; Melissa officinalis; } \\
\text { Mentha arvensis; Pimpinella anisum; } \\
\text { Quercus cortex; Syzygium aromaticum, } \\
\text { Thymus vulgaris }\end{array}$ & $\begin{array}{l}\text { Bacitracin } \\
\text { methylene } \\
\text { disalicylate }^{1}\end{array}$ & Cobb & 1-39 days \\
\hline PUVACA et al. (2015) & $\begin{array}{c}\text { Allium sativum; Piper nigrum; Capsicum } \\
\text { frutescens }\end{array}$ & - & Ross & $1-42$ days \\
\hline $\begin{array}{l}\text { VÁZQUEZ et al. } \\
(2015)\end{array}$ & $\begin{array}{c}\text { Origanum vulgare; Thymus vulgaris; } \\
\text { Piper cubeba }\end{array}$ & - & Ross & 1-39 days \\
\hline $\begin{array}{l}\text { HASHEMIPOUR et al. } \\
\qquad(2016)\end{array}$ & Thymus vulgaris; Origanum vulgare & - & Ross & $1-42$ days \\
\hline $\begin{array}{l}\text { MONA et al. (2016), } \\
\text { TURCU et al. (2018) }\end{array}$ & Origanum vulgare & $\begin{array}{l}\text { Toltrazuril', } \\
\text { Monensin }\end{array}$ & Cobb & 1-42 days \\
\hline KIM et al. (2016) & Ginkgo biloba; Camellia sinensis & - & Ross & $1-35$ days \\
\hline $\begin{array}{l}\text { SKOUFOS et al. } \\
\qquad(2016)\end{array}$ & Origanum vulgare & - & Ross & 1-44 days \\
\hline HAFEEZ et al. (2016) & $\begin{array}{l}\text { Mentha arvensis e Pimpinella anisum; } \\
\text { Thymus vulgaris; Citrus limonum }\end{array}$ & - & Cobb & 1-42 days \\
\hline $\begin{array}{l}\text { MAIDALA et al. } \\
(2016)\end{array}$ & $\begin{array}{c}\text { Azandiracta indica; Guiera senegalensis; } \\
\text { Commiphora kerstinguii }\end{array}$ & - & - & $1-56$ days \\
\hline $\begin{array}{l}\text { GLAMOCLIJA et al. } \\
\qquad(2016)\end{array}$ & $\begin{array}{c}\text { Cuminum cyminum, Mentha arvensis, } \\
\text { Syzygium aromaticum; Pimpinella } \\
\text { anisum }\end{array}$ & - & Cobb & $1-42$ days \\
\hline JADHAV et al. (2016) & $\begin{array}{l}\text { Cisssus quadrangulares; Lepidium } \\
\text { sativum, Uraria picta; Zingiber officinale }\end{array}$ & - & - & $1-42$ days \\
\hline $\begin{array}{l}\text { KALANTAR et al. } \\
(2017)\end{array}$ & Thymus vulgaris ; Glycyrrihiza galabra & - & - & $1-42$ days \\
\hline $\begin{array}{l}\text { RAPHAËL et al. } \\
(2017)\end{array}$ & Dichrostachys glomerata Chiov. & Doxycycline $^{1}$ & Cobb & $1-49$ days \\
\hline ZAMORA et al. (2017) & Origanum vulgare & Oxytetracycline ${ }^{2}$ & Ross & $1-42$ days \\
\hline $\begin{array}{l}\text { PARASKEUAS et al. } \\
(2017)\end{array}$ & $\begin{array}{c}\text { Mentha arvensis; Pimpinella anisum L. } \\
\text { eEugenia aromaticum }\end{array}$ & (3) & Cobb & $1-42$ days \\
\hline $\begin{array}{l}\text { SHEORAN et al. } \\
(2017)\end{array}$ & Allium sativum; Ocimum sanctum & - & Cobb & 42 days \\
\hline FASCINA et al. (2017) & $\begin{array}{l}\text { Vitis sp; Cinnamomum zeylanicum; } \\
\text { Peumus boldus; Trigonella foenum }\end{array}$ & $\begin{array}{l}\text { Avilamycin }{ }^{1} \text { Mone } \\
\text { nsin sodium }\end{array}$ & Cobb & $1-42$ days \\
\hline NIETO et al. (2018) & Lippia origanoides, Origanum vulgare & Bacitracin & Ross & 1-42 days \\
\hline NOLETO et al. (2018) & Copaiphera sp. & Avilamycin & Cobb & $1-40$ days \\
\hline JIÃO et al. (2019) & Salicornia herbacea & - & Ross & $1-35$ days \\
\hline
\end{tabular}

${ }^{*}$ Classification of antibiotic types as action spectrum: 1- Action on gram-positive bacteria. 2- Action on gram-positive and gram-negative bacteria. $\Psi$ Indian Chicken crossbreed.

Allium sativum (7.0\%), or garlic, has two active ingredients: allicin and garlicin. Their predominantly bacteriostatic action acts against both gram-positive and gram-negative bacteria. Garlic is reported to have antimicrobial, antiseptic, antifungal, antiviral, antioxidant, anticancer, immunostimulating properties (RIED 2016). Moreover, it has hypoglycemic properties; it helps reduce blood glucose levels by stimulating insulin secretion through $\beta$ cells in the pancreas. 
The Cobb and Ross breeds were referred to the most in the studies, representing $37.9 \%$. The IBL- 80 and Hubbard breeds were examined in $6.9 \%$ and $3.4 \%$ of the studies, respectively, while $13.8 \%$ of the studies did not provide specific data on the chicken breed and only disclosed that it was a commercial breed. The suppression of this type of information is not helpful from a scientific point of view, as these data are extremely relevant to assessing several parameters of production and establishing a close relationship with the breed.

The Cobb breed presents the best productive performance among the different commercial breeds available for production in the world, mainly due to better weight gain, higher resistance to temperature management, and high rearing density. Additionally, the breed has a high muscle deposition capacity, resulting in better feed conversion. Only in one study, the use of birds of the IBL 80 breed was observed, which according to ICAR (2017) is among the improved varieties widely used in India.

There was a higher prevalence of studies that used a period of 1 to 42 days $(51,7 \%$ of the studies). Studies with periods ranging from 1 to 35 days, 1 to 39 days, and 1 to 49 days corresponded to $20.7 \%$, $10.3 \%$, and $6.8 \%$ of the studies, respectively, and $3.4 \%$ of the studies applied periods of 1 to 21 days, 1 to 44 days, and 1 to 56 days. The use of phytogenic feed additives improves the viability of animal production and allows for better indices of productive efficiency, especially when there are health challenges (FERNANDES et al. 2015).

The weight gain of the chickens increased with the use of phytogenic additives (5\%) and with the use of antibiotics (3.5\%) in relation to the control. Feed consumption decreased with the use of phytogenics (1\%) and antibiotics $(0.2 \%)$ compared to the control. Thus, there was an effect on the feed conversion rate, which showed a reduction with the use of phytogenic additives or antibiotics $(5.6 \%)$, being similar to the control. The mortality rate of chickens decreased with the use of phytogenics $(42 \%)$ and with the use of antibiotics $(57.1 \%)$ compared to the control. These results demonstrate a significant potential for replacing antibiotics with phytogenic additives.

Research has evidenced the efficiency of essential oils, as presented by NIETO et al. (2018), who concluded that chickens fed with the essential oil of Origanum vulgare at a concentration of $500 \mathrm{~g} / \mathrm{ton}$ grow just as fast as chickens fed a diet containing $50 \mathrm{~g} /$ ton bacitracin, explaining that this response occurs by increasing the bird's digestibility and energy use. Upon evaluating the performance of chickens between the ages of 1 to 49 days and the use of thyme and oregano essential oils, RUBEN et al. (2018) observed that weight gain increased by $20 \%$ and $8 \%$, respectively, compared to the control diet, in addition to a higher feed conversion rate.

Findings by ALI et al. (2019) point to an improved performance in broilers fed with ginger, which may be associated with improvements in palatability and the digestive process. According to RAZA et al. (2016), ginger contains several important pharmacological compounds, such as gingerdione, ginger diol, shogaols, and gingerol. In comparing the data on the histomorphology of the intestinal wall, as illustrated in Table 2, the use of phytogenics and commercial antibiotics increased by $13.6 \%$ and $9.3 \%$, respectively, in relation to nonuse (control basal diet). As for crypt depth, it was possible to identify a decrease with the use of phytogenics $(1.1 \%)$ and an increase with the use of antibiotics $(7 \%)$ in comparison to the control. Consequently, there was a direct impact on the villus/crypt ratio which resulted in a $35.4 \%$ increase for phytogenics and a $50.7 \%$ decrease for antibiotics when compared to non-use (control diet). With regard to the villi's surface, the use of phytogenics reduced the surface area of the birds' intestinal villi in comparison to the control. No assessment was made on the use of antibiotics.

With respect to the thickness of intestinal mucosa, thickness decreased with the application of phytogenic feed additives $(2.6 \%)$ and antibiotics $(21.1 \%)$ in relation to the control. As for the muscular thickness of the birds' intestines, an increase of $81.4 \%$ was detected with phytogenics when compared to the control basal diet, while the use of antibiotics was not assessed.

PELíCIA et al. (2015) analyzed the effect of phytogenic additives on the histomorphometry of the small intestine of birds at seven days of age and found that treatment with phytogenic feed additives affected the villus height and crypt depth of the duodenum and ileum segments.

FERNANDES et al. (2017) examined the incorporation of plant extracts in the diet of birds challenged by the coccidiosis vaccine. As a result, they detected an improvement in the excretion of immunoglobulins from the intestinal mucosa of broilers at 42 days of age, which indicates that the applied plant extract might have a stimulating effect on the local defense system of the intestinal mucosa.

MOHITI-ASLI \& RASHTI (2018) demonstrated that 300 ppm of oregano essential oil as dietary supplementation improved the histomorphological properties of the intestine, such as villus height and surface area. 
Table 2. Histomorphology of the intestinal wall of broilers in different studies comparing the use of control diets (CON), phytogenic feed additives (PHY), and antibiotics (ANTI).

\begin{tabular}{|c|c|c|c|c|c|c|c|c|c|}
\hline \multirow{2}{*}{ Author } & \multicolumn{3}{|c|}{ Lenght of villi $(\mu \mathrm{m})$} & \multicolumn{3}{|c|}{ Crypt depth $(\mu \mathrm{m})$} & \multicolumn{3}{|c|}{ Villi/ Crypt $(\mu \mathrm{m})$} \\
\hline & CON & PHY & ANTI & $\mathrm{CON}$ & PHY & ANTI & $\mathrm{CON}$ & PHY & ANTI \\
\hline \multirow{2}{*}{$\begin{array}{l}\text { HASHEMI \& DAVOODI (2011) } \\
\text { OLUKOSI et al. (2014) }\end{array}$} & 866.0 & 975.0 & - & 185.0 & 166.7 & - & 4.7 & 5.9 & - \\
\hline & 558.0 & 787.0 & - & 57.7 & 83.5 & - & 2.9 & 9.4 & - \\
\hline $\begin{array}{l}\text { KHATTAK et al. (2014) } \\
\text { MURUGESAN et al. (2015) }\end{array}$ & $\begin{array}{l}291.0 \\
239.4\end{array}$ & $\begin{array}{l}301.0 \\
301.1\end{array}$ & $-\overline{3}-5$ & $\begin{array}{l}101.0 \\
36.4\end{array}$ & $\begin{array}{l}98.6 \\
28.2\end{array}$ & $-\overline{34.9}$ & $\begin{array}{l}2.9 \\
6.6\end{array}$ & $\begin{array}{l}3.1 \\
10.7\end{array}$ & $\overline{8} 8$ \\
\hline SINGH et al. (2015) & 1412.5 & 1666.7 & 1419.8 & 95.2 & 88.7 & 87.2 & 14.8 & 18.8 & 16.3 \\
\hline \multirow{2}{*}{$\begin{array}{l}\text { SKOUFOS et al. (2016) } \\
\text { FASCINA et al. (2017) }\end{array}$} & 1445.6 & 1488.1 & & 154.3 & 162.0 & & 9.4 & 9.2 & - \\
\hline & 858.3 & 9240 & 931.0 & 205.0 & 197.6 & 210.3 & 4.2 & 4.7 & 4.4 \\
\hline \multirow{2}{*}{$\begin{array}{ll}\text { MOHITI-ASLI \& } & \text { RASHTI } \\
\text { (2018) (jejunum) } & \\
\text { MOHITI-ASSI } & \text { RASHTT }\end{array}$} & & & & & & & & & \\
\hline & 608.1 & 641.37 & - & 109.2 & 86.3 & - & 5.6 & 7.8 & - \\
\hline (2018) (ileum) & 276.4 & 315.7 & - & 66.9 & 63.4 & - & 4.1 & 5.0 & - \\
\hline NOLETO et al. (2018) & 1,255 & 1,354 & 1,346 & 356.9 & 438.2 & 412.0 & 3.62 & 3.18 & 3.31 \\
\hline Average & 781,03 & 875,40 & 1000,75 & 136,76 & 141,32 & 186,10 & 5,88 & 7,78 & 8,20 \\
\hline \multirow[t]{2}{*}{ Author } & \multicolumn{3}{|c|}{ Villi surface area $\left(\mu \mathrm{m}^{2}\right)$} & \multicolumn{3}{|c|}{$\begin{array}{l}\text { Intestinal mucosa thickness } \\
\left(\mu \mathrm{m}^{2}\right)\end{array}$} & \multicolumn{3}{|c|}{$\begin{array}{l}\text { Intestinal muscle } \\
\text { thickness }\left(\mu \mathrm{m}^{2}\right)\end{array}$} \\
\hline & CON & PHY & ANTI & CON & PHY & ANTI & CON & PHY & ANTI \\
\hline \multirow{2}{*}{$\begin{array}{l}\text { HASHEMI \& DAVOODI (2011) } \\
\text { OLUKOSI et al. (2014) }\end{array}$} & $33.19 \times 10^{4}$ & $55.4 \times 10^{4}$ & - & 230.0 & 302.3 & & 12.9 & 14.9 & - \\
\hline & - & - & - & - & - & - & - & - & - \\
\hline \multirow{2}{*}{$\begin{array}{l}\text { KHATTAK et al. (2014) } \\
\text { MURUGESAN et al. (2015) }\end{array}$} & $9.4 \times 10^{4}$ & $10.4 \times 10^{4}$ & - & - & - & - & - & - & - \\
\hline & - & - & - & 304.7 & 218.4 & 211.1 & - & - & - \\
\hline SINGH et al. (2015) & - & - & - & - & - & - & - & - & - \\
\hline \multirow{2}{*}{$\begin{array}{l}\text { SKOUFOS et al. (2016) } \\
\text { FASCINA et al. (2017) }\end{array}$} & - & - & - & - & - & - & - & - & - \\
\hline & - & - & - & - & - & - & - & - & - \\
\hline Average & $212.9 \times 10^{4}$ & $32.9 \times 10^{4}$ & - & 267.4 & 260.4 & 211.1 & 12.9 & 14.9 & - \\
\hline
\end{tabular}

VILLI/CRYPT $=$ Relationship between length of villi and crypt depth.

The biochemical profile (Table 3) reveals that the use of phytogenics and antibiotics reduced cholesterol by $7.4 \%$ and $14.6 \%$, respectively, in relation to non-use (control diet). HDL (high-density lipoprotein) rose by $15.3 \%$ with phytogenics and by $9.1 \%$ with antibiotics in comparison to the control diet. LDL (low-density lipoprotein) in the blood fell by $25.3 \%$ and $4.33 \%$ with the application of phytogenics and commercial antibiotics, respectively, compared to non-use (control diet).

As for VLDL ( $\mathrm{mg} / \mathrm{dl})$, it rose by $29.8 \%$ with phytogenics and by $38.5 \%$ with antibiotics in comparison to the Control diet. Therefore, there was a direct impact on the HDL/LDL ratio, which elevated $84.61 \%$ in relation to the control, while the effect of antibiotic use on this ratio was not evaluated. The physiological responses in connection to the animal's internal factors, such as age and sex, and external factors, such as diet and environment, were reflected directly in the biochemical profile and can provide information on the animal's metabolism and health (YARI et al. 2014).

In chickens supplemented with medicinal plants, serum triglyceride levels lowered. DOMINGUES et al. (2016) investigated the use of pepper in high and low digestibility diets. In high digestibility diets, they observed that the biochemical profile data were within the recommended limits for birds. There was a difference in cholesterol levels in the low digestibility diet; however, they did not exceed the recommended limits.

A comparison of the carcass characteristics, as shown in Figure 1, reveals that there was a $7.5 \%$ increase in the birds' breast percentage with phytogenic application in relation to non-use (control basal diet). Nevertheless, when antibiotics were used, there was a $42.26 \%$ decrease in comparison to the control diet. With the use of phytogenics, the leg registered the same percentage $(3.2 \%)$ as the control diet. With antibiotics, it increased by $6.3 \%$ in relation to non-use (control diet). The amount of abdominal fat in birds treated with phytogenic feed additives remained the same as those treated with the control diet. In comparison to antibiotic use, there was a $12.5 \%$ reduction. The liver decreased by $4.3 \%$ and $13.0 \%$ with the application of phytogenics and antibiotics, respectively, compared to the control diet. The heart remained unchanged in its values with the use of phytogenics and commercial antibiotics.

Carcass yield increased by $4.4 \%$ and $6.4 \%$ with the use of phytogenic feed additives and antibiotics, respectively, in relation to the control diet. The percentage for gizzards with regard to phytogenic application remained unchanged, while the use of antibiotics decreased by $10.5 \%$ in comparison to the basal diet. The spleen and the bursa of Fabricius increased by one percent with phytogenics in relation to non-use (control 
basal diet), and they remained equivalent in the comparison between antibiotics and the control.

Table 3. Biochemical profile of broilers in different studies comparing the use of control diets (CON), phytogenic feed additives (PHY), and antibiotics (ANTI).

\begin{tabular}{|c|c|c|c|c|c|c|c|c|c|}
\hline \multirow{2}{*}{ Author } & \multicolumn{3}{|c|}{ Cholesterol (mg/dl) } & \multicolumn{3}{|c|}{ Triglycerid $(\mu \mathrm{m})$} & \multicolumn{3}{|c|}{$\mathrm{HDL}(\mathrm{mg} / \mathrm{dl})$} \\
\hline & CON & PHY & ANTI & CON & PHY & ANTI & CON & PHY & ANTI \\
\hline HASHEMI \& DAVOODI (2011) & 113.3 & 127.6 & - & 85.9 & 84.1 & - & - & - & - \\
\hline CHO et al. (2014) & 119.0 & 101.0 & 121.0 & 107.0 & 110.0 & 102.0 & 51.4 & 63.6 & 57.5 \\
\hline SINGH et al. (2015) & 133.3 & 117.9 & 124.0 & 106.0 & 96.2 & 99.1 & - & - & - \\
\hline PUVACA et al. (2015) & 97.2 & 54.6 & - & 65.9 & 18.2 & - & 19.2 & 37.1 & - \\
\hline HASHEMIPOUR et al. (2016) & 121.0 & 101.1 & - & 77.1 & 75.4 & - & 82.2 & 83.3 & - \\
\hline MONA et al. (2016) & 3.9 & 3.2 & 4.0 & - & - & - & - & - & - \\
\hline ZAMORA et al. (2017) & 121.4 & 138.4 & 104.2 & 28.7 & 37.0 & 39.5 & 69.0 & 72.1 & 58.8 \\
\hline PARASKEUAS et al. (2017) & 118.0 & 121.9 & - & 33.2 & 31.1 & - & - & - & - \\
\hline REIS et al. (2018) (28days) & 99.00 & 87.83 & 85.00 & - & - & - & - & - & - \\
\hline Average & 102.9 & 94.84 & 85.00 & 72.0 & 64.6 & 80.2 & 55.5 & 64.0 & 58.2 \\
\hline \multirow{2}{*}{ Author } & \multicolumn{3}{|c|}{$\mathrm{LDL}(\mathrm{mg} / \mathrm{dl})$} & \multicolumn{3}{|c|}{$\operatorname{VLDL~}(\mathrm{mg} / \mathrm{dl})$} & \multicolumn{3}{|c|}{ HDL/LDL } \\
\hline & $\mathrm{CON}$ & $\mathrm{PHY}$ & ANTI & CON & $\mathrm{PHY}$ & ANTI & CON & $\mathrm{PHY}$ & ANTI \\
\hline HASHEMI \& DAVOODI (2011) & - & - & & - & - & - & - & - & - \\
\hline CHO et al. (2014) & 46.4 & 36.7 & 42.0 & - & - & - & 1.1 & 1.7 & - \\
\hline SINGH et al. (2015) & - & - & - & - & - & - & - & - & - \\
\hline PUVACA et al. (2015) & 36.7 & 9.2 & - & - & - & - & 0.5 & 4.0 & - \\
\hline HASHEMIPOUR et al. (2016) & 36.1 & 32.4 & - & - & - & - & 2.3 & 2.3 & - \\
\hline MONA et al. (2016) & - & - & - & - & - & - & - & - & - \\
\hline ZAMORA et al. (2017) & 46.7 & 45.5 & 37.4 & 5.7 & 7.4 & 7.9 & 1.5 & 1.6 & - \\
\hline PARASKEUAS et al. (2017) & - & - & - & - & - & - & - & - & - \\
\hline Average & 41.5 & 31.0 & 39.7 & 5.7 & 7.4 & 7.9 & 1.3 & 2.4 & - \\
\hline
\end{tabular}

In a previous study, KOIYAMA et al. (2014) evaluated the effect of combinations of phytogenic additives in the broiler diet on animal performance and carcass yield. Throughout the entire experimental period, the use of antibiotics and combined phytogenic additives resulted in greater weight gain for the birds. The combined phytogenic feed additives and the control treatment provided greater leg yield, and the relative weight of the spleen was also greater. Thus, the authors concluded that the combined phytogenic feed additives show potential as performance enhancers for broiler chickens. IPÇAK \& ALÇIÇEK (2018) observed improvements in the quality of the final product upon evaluating the carcass quality of Ross chickens between the ages of one to 42 days and the use of the herbal medicines Capsicum, oleoresin, Carvacrol, and Cinnamaldehyde. The results were positive when applied separately or as a mixture at a dose of 150 $\mathrm{mg} / \mathrm{kg}$, with beneficial effects in relation to the meat's flavor, tenderness, and juiciness. Similarly, upon assessing the carcass quality of Ross chickens between the ages of 1 to 35 days that had been supplemented with the herbicide Salicornia, JIÃO et al. (2019) indicated that a supplemention of $5 \mathrm{cc} / \mathrm{L}$ of $S$. herbacea for chickens achieved a response in meat quality and in the birds' performance and growth.

As for bacterial colonization in the birds' intestines, Figure 2 demonstrates that the use of phytogenic feed additives and commercial antibiotics reduced total E. coli bacteria by $50.9 \%$ and $32.1 \%$, respectively, when compared to non-use (control basal diet).

Lactobacillus increased with the use of phytogenics (40.3\%) and antibiotics $(6.0 \%)$ in relation to the Control. The numbers corresponding to Clostridia reduced by $31.5 \%$ and $20.5 \%$ with phytogenic feed additives and antibiotics, respectively, in comparison to the control. Bifidobacterium remained the same in the comparison between phytogenic and the control diet but declined by $8.8 \%$ with the use of antibiotics in relation to the control diet. The use of phytogenic feed additives lowered the amount of salmonella in the birds by $15 \%$ and by $54.2 \%$ with antibiotics in comparison to non-use (control diet).

MOHITI-ASLI \& RASHTI (2018) observed a distinct decrease in the E. coli count, as a pathogenic microorganism in the chickens' intestines, with the application of $300 \mathrm{ppm}$ and $500 \mathrm{ppm}$ of oregano essential oil in relation to the control diet and a diet incorporating commercial product. In TURCU et al. (2018), broilers Rev. Ciênc. Agrovet., Lages, SC, Brasil (ISSN 2238-1171) 
were supplemented with Origanum vulgare in the form of oil and powder, and upon evaluating intestinal microbiota, the authors noted that the total number of enterobacteriaceae, E. coli, and staphylococci decreased significantly in comparison to the control group. The total number of lactobacilli increased significantly in experimental diets in relation to the control diet.
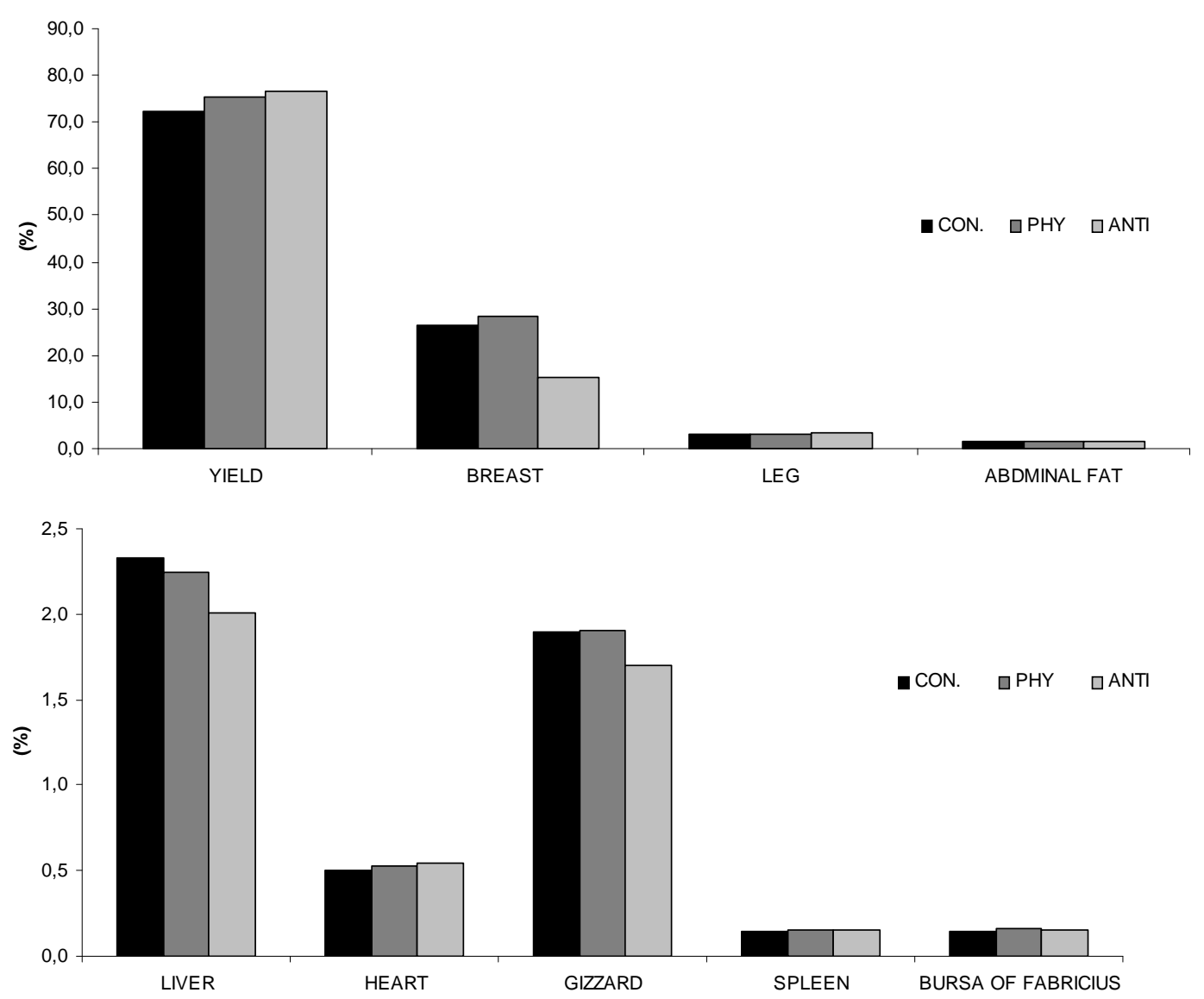

Figure 1. Carcass characteristics of broilers in different studies comparing the use of control diets (CON), phytogenic feed additives (PHY), and antibiotics (ANTI).

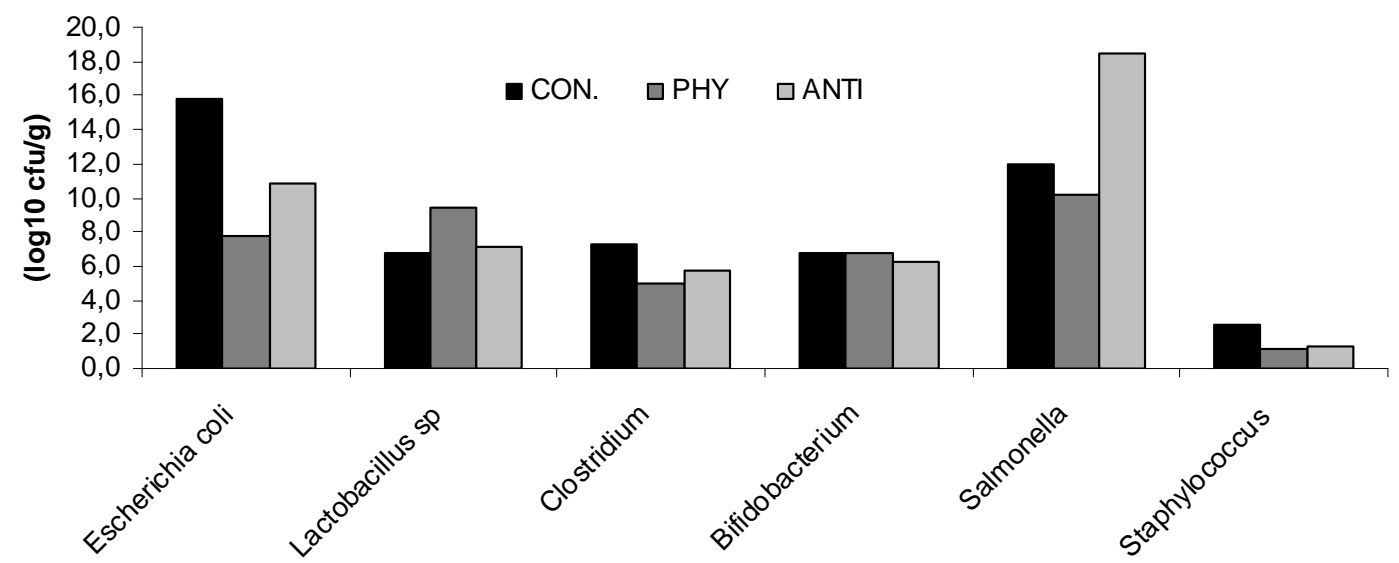

Figure 2. Bacteria found in the intestines of broilers in different studies comparing the use of control diets, phytogenic feed additives, and antibiotics.

ALI et al. (2019) observed a significant decrease in the oocyst count in birds supplemented with phytogenics (garlic) during the 5th, 7th, 9th, and 11th day after infection and argue that the presence of allicin in garlic provoked this decrease in infestation. Allicin has antioxidant and antiparasitic activity and stimulates the immune response by the increase in profilin antibodies that directly kill the sporozoites. 


\section{CONCLUSION}

The use of phytogenic feed additives positively influences zootechnical performance, the histomorphology of the intestinal wall, the biochemical profile, carcass characteristics, and the bacterial intestinal profile of broilers in comparison to antibiotics and control (basal diet).

\section{ACKNOWLEDGEMENTS}

This study was funded in part by the Coordination for the Improvement of Higher Education Personnel (CAPES) in Brazil - Funding Code 001.

\section{REFERENCES}

ALI M et al. 2019. Anticoccidial effect of garlic (Allium sativum) and ginger (Zingiber officinale) against experimentally induced coccidiosis in broiler chickens. Journal of Applied Animal Research 47: 79-84.

BORGES AM et al. 2012. Determination of essential oils of basil (Ocimum gratissimum L.), oregano (Origanum vulgare L.) and thyme (Thymus vulgaris L.). Brazilian Journal of Medicinal Plants 14: 656-665.

BOZKURT M et al. 2014. Effects of selected herbs and essential oils on performance, egg quality and some metabolic activities in laying hens - a review. European Poultry Science 78: 1-15.

$\mathrm{CHO} \mathrm{JH}$ et al. 2014. Effects of phytogenic feed additive on growth Performance, digestibility, blood metabolites, intestinal microbiota, meat color and relative organ weight after oral challenge with Clostridium perfringens in broilers. Livestock Science 160: 82-88.

DOMINGUES RM et al. 2016. Blood parameters of broilers fed diets supplemented with dry seeds of Piper cubeba as a phytogenic additive. Brazilian Veterinary Research 36: 1139-1144.

FASCINA VB et al. 2017. Effects of Phytogenic Additives and Organic Acids, alone or in combination, on the Performance, Intestinal Quality and Immune Responses of Broiler Chickens. Brazilian Journal of Poultry Science 19: 497-508.

FERENHOF HA \& FERNANDES RF. 2016. Demystifying literature review as a basis for scientific writing: SSF method. Revista ACB 21: 550-563.

FERNANDES JIM et al. 2017. Evaluation of plant extracts on the immune response, productive performance and intestinal morphometry of broilers challenged with Eimeria sp. Brazilian Journal of Health and Animal Production 18: 127-139.

FERNANDES RTV et al. 2015. Phytogenic additives in broiler feed: essential oils and spices. Veterinary Publications 9: 526-535.

GLAMOCLIJA N et al. 2016. Effects of phytobiotics on Cobb broiler production results, meatiness and chemical composition. Meat Technology 57: 89-94.

HAFEEZ A et al. 2016. Effect of supplementation of phytogenic feed additives (powdered vs. encapsulated) on performance and nutrient digestibility in broiler chickens. Poultry Science 95: 622-629.

HASHEMI SR \& DAVOODI H. 2011. Herbal plants and their derivatives as growth and health promoters in animal nutrition. Veterinary Research Communications 35: 169-180.

HASHEMIPOUR $\mathrm{H}$ et al. 2016. Effect of feed supplementation with a thymol plus carvacrol mixture, in combination or not with an NSP-degrading enzyme, on productive and physiological parameters of broilers fed on wheat-based diets. Animal Feed Science and Technology 211: 117-131.

ICAR. 2017. Annual Report 2016-2017. AICRP on Poultry Breeding and Poultry Seed Project. Directorate of Poultry Research. Hyderabad: ICAR.

IPÇAK HH \& ALÇIÇEK A. 2018. Addition of Capsicum oleoresin, Carvacrol, Cinnamaldehyde and their mixtures to the broiler diet II: Effects on meat quality. Journal of Animal Science and Technology 60: 1-11.

JADHAV NV et al. 2016. Effect of calcium, phosphorus premix with synergistic herbs supplementation in improving overall performance, carcass quality and tibial mineralization in broiler chickens. Journal of Advanced Veterinary and Animal Research 3: 268-273.

JIÃO Y et al. 2019. Effects of Salicornia herbacea on Growth Performance, Meat Quality, Excreta Microbial Populations, and Noxious Gas Emissions in Broiler Chicks. Journal Poultry Science 56: 44-51.

KALANTAR M et al. 2017. Performance, Immune, and Carcass Characteristics of Broiler Chickens as Affected by Thyme and Licorice or Enzyme Supplemented Diets. Open Journal of Animal Sciences 7: 105-109.

KHATTAK FA et al. 2014. Effects of natural blend of essential oil on growth performance, blood biochemistry, cecal morphology, and carcass quality of broiler chickens. Poultry Science 93:132-137.

KIM YJ et al. 2016. Effect of fermented Ginkgo biloba and Camelia sinensis-based probiotics on growth performance, immunity and caecal microbiology in broilers. International Journal of Poultry Science 15: 62-71.

KOIYAMA NTG et al. 2014. Growth performance and carcass yield of chicken broiler diets with mixtures of phytogenic additives. Brazilian Agricultural Research 49: 225-231.

LI HL et al. 2015. Phytoncide, phytogenic feed additive as an alternative to conventional antibiotics, improved growth performance and decreased excreta gas emission without adverse effect on meat quality in broiler chickens. Livestock Science 181: 1-6.

MADHUPRIYA V et al. 2018. Phyto Feed Additives in Poultry Nutrition: A Review. International Journal of Science Rev. Ciênc. Agrovet., Lages, SC, Brasil (ISSN 2238-1171) 
Education 7: 815-822.

MAIDALA A et al. 2016. Carcass Yield and Gut Characteristics of Broiler Chickens Fed Different Types of Phytogenic Plant Leaf. Journal of Science, Technology \& Education 4: 22-29.

MOHITI-ASLI M \& RASHTI MG. 2018. Comparing the effects of a combined phytogenic feed additive with an individual essential oil of oregano on intestinal morphology and microflora in broilers. Journal of Applied Animal Research 46: 184-189.

MONA AE et al. 2016. Effect of Phytobiotics, Probiotics and Toltrazuril on Chicken Coccidiosis. Zagazig Veterinary Journal 44: 214-223.

MURUGESAN GR et al. 2015. Phytogenic feed additives as an alternative to antibiotic growth promoters in broiler chickens. Frontiers in Veterinary Science 2: 21.

NIETO CA et al. 2018. Effect of two chemotypes of oregano essential oil on Broiler performance, nutrient balance, and lipid Peroxidation of breast meat du- ring storage. Brazilian Animal Science 19: 1-15.

NOLETO RA et al. 2018. Supplementation of copaiba or sucupira oils in broiler diets. Brazilian Journal of Health and Animal Production 19: 83-92.

OLUKOSI AO et al. 2014. Modification of digesta $\mathrm{pH}$ and intestinal morphology with the use of benzoic acid or phytobiotics and the effects on broiler chicken growth performance and energy and nutrient utilization. Journal of Animal Science 92: 3945-3953.

PARASKEUAS V et al. 2017. Growth performance, nutrient digestibility, antioxidant capacity, blood biochemical biomarkers and cytokines expression in broiler chickens fed different phytogenic levels. Animal Nutrition 3: 114-120.

PATI P et al. 2015. Effect of inclusion of ginger (Zingiber officinale) waste meal in the diet on broiler performance. Indian Journal of Animal Nutrition 32: 305-309.

PELÍCIA VC et al. 2015. Tropic action of phytogenic additives, glutamine and glutamic acid on Bursa Fabricio and small intestines of broilers. Brazilian Veterinary Research 35: 691-699.

PULICI PMM et al. 2014. Use of essential oil of oregano, salinomycin and zinc bacitracin in the diet of broilers. Brazilian Journal of Veterinary Research and Animal Science 51:131.

PUVACA N et al. 2015. Effect of garlic, black pepper and hot red pepper on productive performances and blood lipid profile of broiler chickens. European Poultry Science 79: 13p.

RAPHAËL KJ et al. 2017. Effect of Dietary Mimosa Small Bell (Dichostachys glomerata) Fruit Supplement as Alternative to Antibiotic Growth Promoter for Broiler Chicken. Journal of World's Poultry Research 7: 27-34.

RAZA T et al. 2016. Improving the fatty acid profile in egg yolk through the use of hempseed (Cannabis sativa), ginger (Zingiber officinale), and turmeric (Curcuma longa) in the diet of Hy-Line White Leghorns. Archives Animal Breeding 68: 183-190.

REIS JH et al. 2018. Effects of phytogenic feed additive based on thymol, carvacrol and cinnamic aldehyde on body weight, blood parameters and environmental bacteria in broilers chickens. Microbial Pathogenesis 125: 168-176.

RIED K. 2016. Garlic Lowers Blood Pressure in Hypertensive Individuals, Regulates Serum Cholesterol, and Stimulates Immunity: An Updated Meta-analysis and Review. Journal of Nutrition 146: 389S-396S.

RUBEN NT et al. 2018. Effects of dietary thyme and oregano essential oils entrapped in chitosan and Canarium charcoal stable matrix on growth performances in broiler chickens. International Journal of Innovation and Applied Studies 22 : 114-122.

SHEORAN $\mathrm{N}$ et al. 2017. Nutrigenomic evaluation of garlic (Allium sativum) and holy basil (Ocimum sanctum) leaf powder supplementation on growth performance and immune characteristics in broilers. Veterinary World 10: 121-129.

SIMÕES CMO et al. 2017. Pharmacognosy: from natural product to medicine. Porto Alegre: Artmed.

SINGH J et al. 2015. Effect of sun dried whole bulb garlic powder on growth, carcass characteristics and meat quality of commercial broilers. Indian Journal of Animal Sciences 85: 67-71.

SKOUFOS I et al. 2016. Effects of oregano essential oil and attapulgite on growth performance, intestinal microbiota and morphometry in broilers. South African Journal of Animal Science 46: 77-88.

TURCU RP et al. 2018. Effect of the dietary oregano (Origanum vulgare L.) powder and oil on the balance of the intestinal microflora of broilers reared under heat stress $\left(32^{\circ} \mathrm{C}\right)$. Animal Science $51: 77-86$.

VÁZQUEZ RS et al. 2015. Performance of broiler chickens supplemented with Mexican oregano oil (Lippia berlandieri Schauer). Brazilian Journal of Animal Science 44: 283-289.

WATI T et al. 2015. Comparative efficacy of a phytogenic feed additive and an antibiotic growth promoter on production performance, caecal microbial population and humoral immune response of broiler chickens inoculated with enteric pathogens. Animal Nutrition 1: 213-219.

YARI P et al. 2014. Productive and serum biological responses of broiler chicks to use of different patterns of diet formulation. International Journal of Plant, Animal and Environmental Sciences 4: 459-464.

ZAMORA GM et al. 2017. Performance, blood parameters, and carcass yield of broiler chickens supplemented with Mexican oregano oil. Brazilian Journal of Animal Science 46: 515-520.

ZHAI H et al. 2018. Potential of essential oils for poultry and pigs. Animal Nutrition 4: 179-186. 